\title{
Online mental health care during the COVID-19 pandemic
}

\author{
Atendimento on-line em saúde mental durante a pandemia da COVID-19 \\ La atención online en salud mental durante la pandemia de COVID-19
}

Ariane da Cruz Guedes'
ORCID: 0000-0002-5269-787X

Luciane Prado Kantorski'

ORCID: 0000-0001-9726-3162

Janaína Quinzen Willrich

ORCID: 0000-0001-7427-9305

Valéria Cristina Christello Coimbra ORCID: 0000-0001-5327-0141

Carla Gabriela Wünsch"

ORCID: 0000-0002-1263-1120

Lilian Cruz Souto de Oliveira Sperb ORCID: 0000-0001-9654-7470

César Brasil Sperb

ORCID: 0000-0003-0268-9289

'Universidade Federal de Pelotas. Pelotas, Rio Grande do Sul, Brazil.

"Universidade Federal do Mato Grosso. Cuiabá,

Mato Grosso, Brazil.

How to cite this article: Guedes AC, Kantorski LP, Willrich JQ, Coimbra VCC Wünsch CG, Sperb LCSO, et al. Online menta health care during the COVID-19 pandemic. Rev Bras Enferm. 2022;75(Suppl 1):e20210554. https://doi.org/10.1590/0034-7167-2021-0554

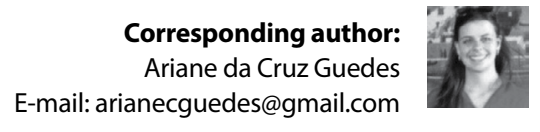

EDITOR IN CHIEF: Dulce Barbosa ASSOCIATE EDITOR: Antonio José de Almeida Filho

\begin{abstract}
Objective: Identify users, services, and reasons for seeking online mental health care during the COVID-19 pandemic. Methods: A descriptive, retrospective study, with documentary analysis of medical records of users served between April and July 2020. Results: Of the 258 accesses, 159 were complete, and 99 were offline messages. Although there were 61 (38.36\%) consultations in May, in April, there were 49 (30.82\%) in 18 days of reception. More than $89 \%$ of accesses were women between 40 and 59 years. Among the motivations in the search for care, anxiety, fear, depression, sadness, crying, stress, and suicidal ideation stand out. Final considerations: Chat is a quick, early and short-wait intervention opportunity for people in need of mental health care. Therefore, the study emphasizes the importance of investing in the training of nursing professionals to act in mental health.

Descriptors: Mental Health; Remote Consultation; Pandemics; Nursing; Psychology.
\end{abstract}

\section{RESUMO}

Objetivo: Caracterizar os usuários, os atendimentos e as motivações para busca de atendimento online em saúde mental durante a pandemia da COVID-19. Métodos: Estudo descritivo, retrospectivo, com análise documental de prontuários de usuários atendidos entre abril e julho de 2020. Resultados: Dos 258 acessos, 159 foram efetivados, e 99 foram mensagens off-line. Apesar de o mês de maio apresentar 61 (38,36\%) atendimentos, em abril ocorreram 49 (30,82\%) em 18 dias de acolhimento. Mais de 89\% dos acessos foram de mulheres, entre 40 e 59 anos. Das motivações na busca por atendimento, destacam-se a ansiedade, medo, depressão, tristeza, choro, estresse e ideação suicida. Considerações finais: $O$ chat é uma oportunidade de intervenção rápida, precoce e com curto tempo de espera para as pessoas que necessitam de cuidado em saúde mental. Portanto, ressalta-se a importância de se investir na formação de profissionais de enfermagem para a atuação na saúde mental. Descritores: Saúde Mental; Consulta Remota; Pandemias; Enfermagem; Psicologia.

\section{RESUMEN}

Objetivo: Caracterizar usuarios, atenciones y motivaciones para búsqueda de atención online en salud mental durante la pandemia de COVID-19. Métodos: Estudio descriptivo, retrospectivo, con análisis documental de prontuarios de usuarios atendidos entre abril y julio de 2020. Resultados: De los 258 accesos, 159 fueron efectuados, y 99 fueron mensajes desconectadas. Aunque el mes de mayo presentó 61 (38,36\%) atenciones, en abril ocurrieron 49 (30,82\%) en 18 días de recepción. Más de $89 \%$ de los accesos fueron de mujeres, entre 40 y 59 años. De las motivaciones en la búsqueda por atención, destacan la ansiedad, miedo, depresión, tristeza, Iloro, estrés e ideación suicida. Consideraciones finales: El chat es una oportunidad de intervención rápida, precoz y con corto tiempo de espera para las personas que necesitan de cuidado en salud mental. Así, se resalta la importancia de invertir en la formación de profesionales de enfermería para la actuación en la salud mental. Descriptores: Salud Mental; Consulta Remota; Pandemias; Enfermería; Psicología. 


\section{INTRODUCTION}

The current situation that society is living with the pandemic of the new coronavirus is challenging. After examinations and genetic sequencing, studies identified the cause of this new pneumonia: new coronavirus (SARS-CoV-2). It was called coronavirus disease 2019 (COVID-19) and started in Wuhan, China, in December 2019. In early 2020, it spread rapidly around the world, becoming a pandemic ${ }^{(1)}$.

China conducted the first large-scale national study of mental health anxiety survey in the general population during the $\mathrm{CO}$ VID-19 epidemic period. Of the sample of 52,730 valid questionnaires from 36 provinces of China, around 35\% of respondents presented symptoms of anxiety, higher among women and in people over 60 years of age, who were more vulnerable to developing post-traumatic stress ${ }^{(1)}$.

According to a literature review study, preliminary evidence suggests that self-reported symptoms of anxiety and depression $(16 \% ; 28 \%)$ and stress (8\%) are common psychological reactions to the COVID-19 pandemic and may be associated with sleep disorders $^{(2)}$. A study with 1,060 participants in China showed that more than $70 \%$ of them presented high scores for obsessivecompulsive symptoms, interpersonal sensitivity, phobic anxiety, and psychoticism (aggressiveness and interpersonal hostility) ${ }^{(3)}$.

During the pandemic, fear tends to intensify stress and anxiety in healthy people and increase the symptoms of those with pre-existing mental disorders. The social isolation adopted throughout the pandemic, the lack of control, the feeling of uncertainty, the change of plans, the separation of the social and family environment contribute to the increase of anxious and depressive manifestations ${ }^{(4)}$. An integrative review evidenced that people subjected to the necessary social isolation resulting from the pandemic are more susceptible to present mental disorders related to stress, anxiety, and depression. Therefore, they highlighted the importance of ensuring access to clear and informative communication on strategies to reduce these symptoms and of providing psychological and social support to these vulnerable individuals ${ }^{(5)}$.

Although psychological support services traditionally occur through present care, the dangerous risks of contamination, the safety factor, and the popularization of the internet and smartphones made possible the online offer of mental health services during the COVID-19 outbreak. Thus, as the global covid-19 pandemic expands, the potential of digital health for mental health becomes urgent. There is an increased interest in using digital technologies to meet people's demands in quarantine, with social and physical restraints of distancing. Therefore, adopting digital health to the needs of people in mental anxiety is an emerging need ${ }^{(6)}$.

A literature review emphasized the implications of the pandemic on mental health and psychological interventions with a focus on psychoeducational actions through booklets and informative materials, offering channels for psychological listening via telephone or online platforms ${ }^{(7)}$. Another integrative review of the world literature reinforces the need to look for new ways to carry out interventions in mental health, such as online care for coping with the coronavirus, showing weaknesses concerning the preparation of professionals ${ }^{(8)}$.
A relevant and controversial discussion regarding online listening is the bonding issue since some professionals point out difficulties in establishing it in this way of care. The therapeutic bond in online brief gestalt psychotherapy emphasizes the understanding of the processes of subjectivation through discourses, showing that attitudes of love, genuine care, understanding, interest, and adequate language are essential resources for establishing a bond in this type of care ${ }^{(9)}$.

As for intervention in these pandemic-related problems that interfere with mental health, China's experience shows the need for improvements. Countries such as the United Kingdom and the United States have established procedures to intervene in situations of mental health crises in the contexts of humanitarian emergencies. In 2004, China Government issued guidelines. However, problems related to inadequate planning for its implementation, precarious levels of cooperation between general health and specialized mental health services, and shortage of professionals made it impossible to establish psychological intervention teams in many places. As the disease progresses, clinical symptoms become severe, and psychological problems in infected patients change. Therefore, mental health intervention measures should be adapted as needed ${ }^{(10)}$.

In some countries, health institutions and universities have opened online platforms to provide mental health support services to patients, family members, and others affected by the pandemic. In Brazil, however, government initiatives are scarce and focus only on worker health. Also, as the experience of remote mental health care is recent, this has been incorporated as the pandemic progresses, enabling health services and managers to structure new interventions for the psychic sufferings of the population.

To that end, the project to be presented provides an online listening chat for health professionals and the general population. It is a practical mental health intervention in the face of a pandemic scenario, considering the mental sufferings produced in this context.

\section{OBJECTIVE}

Identify users, services, and reasons for seeking online mental health care during the COVID-19 pandemic.

\section{METHODS}

\section{Ethical aspects}

First, we have produced an extension project that was split on a research project titled "The therapeutic listening as a care and reception instrument in the context of the pandemic of the new coronavirus/COVID-19," which has been examined and approved by the Ethics Committee in Research with Human Beings, from the School of Medicine, Federal University of Pelotas (UFPel). Both projects are linked to the Research Group in Nursing, Mental Health, and Collective Health of the Faculty of Nursing of UFPel, which is linked to the National Council for Scientific and Technological Development (CNPq) for 20 years. It is worth noting that, before starting the service in the therapeutic listening chat, the user had digital access to the Free and Informed Consent 
Form, authorizing the collection of data in their medical records, protecting the secrecy and anonymity recommended by the ethical issues of research with human beings.

\section{Type of study}

It is a descriptive, retrospective study with documentary analysis of medical records to describe and identify users and services. The documentary analysis sought to re-examine and find complementary interpretations on the motivations for seeking online mental health care in the period of operation of the chat (between April 13 and July 13) during the COVID-19 pandemic. This article used the checklist and the COREQ guidelines (Consolidated criteria for reporting qualitative research).

\section{Methodological procedures}

The data for this research originates from the records in electronic medical records of the online appointments carried out between April 13 (the date on which the service began) and July 13,2020 . The main objective of the chat was to offer therapeutic listening and online welcoming to the community over 18 , free of charge. The listening channel was disseminated to the general population and academic population through social networks through publications and messages, as well as through journalistic material on the website of the University and the city of Pelotas.

The care team had 24 volunteer professionals from the mental health area: fourteen nurses, seven psychologists, two occupational therapists, and one holistic therapist. Of them, three acted as supervisors. They were professionals of the psychosocial care network of Pelotas and linked to the Federal University of Pelotas through the Graduate Program in Nursing. Professionals specialized in the area and with more than 20 years of experience in mental health conducted the supervision meetings that took place regularly to discuss the cases. All these professionals have extensive experience in present mental health care and received prior training given by two logistics support technicians through audiovisual tutorials and individual guidance to use the tools necessary for interaction with the user.

Clients could access the chat directly from the website address www.gruposaudemental.com/chat. There was also the option of interaction with the professional by videoconferencing in the chat as per the user's choice. There was no limit on calls per person, that is, the client could get in touch whenever he needed to. The user could also leave an offline message when there were no attendants available, that as soon as one was available, they would receive a notice in the email informed when they filled out the registration. On this occasion, one of the professionals explained about the operation of the project and available schedules, inviting the user to return and helping the public not to be unassisted.

To access it, clients filled out a form available on the same electronic page of the chat, which requested the name, phone number, age, gender, city, email address, name and phone numbers of a close friend and, finally, they had to answer if accepted to participate in the research through the Informed Consent Form. In addition, when starting care, the person had to agree to the "Patient consultation consent form."The visits respected the guidelines of the Code of Ethics of Nursing Professionals, based on Resolution 634 of 2020 of the Federal Council of Nursing, which provides for the authorization of nursing teleconsultation as a way to cope the pandemic caused by the new coronavirus ${ }^{(11)}$. After the visits, the professional made the registration in electronic medical records.

For the storage of the electronic medical records, we followed the security criteria on the platform and used the most stringent and current digital security standards. Data storage is protected by the Advanced Encryption Standard (AES-256 bits), and data transfer on the web takes place under the TLS 1.3 (Transport Layer Security) encryption protocol.

\section{Study setting}

Web Portal, therapeutic listening chat.

\section{Data source}

This manuscript presents the data obtained from the medical records of users accompanied in the chat between April and July 2020. Three chat operators carried out the data collection and included the information obtained: (a) from the initial form completed when accessing the chat, in which information was requested about the month of attendance, gender, age, profession/occupation, and locality; (b) from the service platform, as waiting time for care; and (c) from the medical records of the people served, listing the emotions and complaints presented at the reception. The study used only the written records available in the service chat.

\section{Collection and organization of data}

The analysis of the initial form was carried out in an Excel spreadsheet, with the quantification and establishment of its percentages, generating Table 1 presented below. The data on the duration of conversations and the waiting time for attendance were accounted for and provided by the used platform through the "reports" menu. And, finally, the emotions and complaints presented by the person were extracted from the item "Signs and Symptoms (mental state examination)" in the medical records. Such emotions and complaints were added to an online program that generated a representative image through the graphic resource "word cloud".

Word cloud is a data visualization method that, through word processing, selects the words that appear most often and displays them in a larger size in a cloud format. It is a widely used resource for organizing data that intend to interpret the content of the text. Thus, in the present study, each word that emerges more frequently in the database reveals feelings experienced during the pandemic experience and reported during the online intervention.

The data resulting from the processing and organization in the word cloud were interpreted in the light of the literature on mental health in the context of humanitarian emergencies, considering the expressions of the subjects and their place of insertion. These emotional responses, in turn, are shown in Figure 1. 


\section{RESULTS}

Through this study, it was possible to identify the calls made in the listening chat between April 13, the first day of attendance, and July 13, 2020, totaling 258 accesses. Of these, 159 were from appointments with professionals, generating medical records data; and 99 were offline messages left during periods when there was no professional on duty. Regarding offline messages, ten were sent by males, 88 females, and one unidentified.

Conversations are sorted on the platform by duration: short, medium, and long. There were no conversations considered short. The average duration of conversations ranged from $00 \mathrm{~h} 13 \mathrm{~m}$ to $00 \mathrm{~h} 19 \mathrm{~m} 49 \mathrm{~s}$, and the long ones, from $01 \mathrm{~h} 43 \mathrm{~m} 13 \mathrm{~s}$ to $01 \mathrm{~h} 56 \mathrm{~m} 23 \mathrm{~s}$. The waiting time for attendance, after chat accessing, was from 00h00m35s to $00 \mathrm{~h} 16 \mathrm{~m} 09 \mathrm{~s}$.

Table 1 - Identification of online service users concerning gender, age, profession/occupation, location in which they live, and period of service search, Pelotas, Rio Grande do Sul, Brazil, 2020

\begin{tabular}{lcc}
\hline Services & $\mathbf{n}$ & $\%$ \\
\hline Month & 159 & 100 \\
April & 49 & 30.82 \\
May & 61 & 38.36 \\
June & 32 & 20.13 \\
July & 17 & 10.69 \\
Gender & & \\
Male & 17 & 10.69 \\
Female & 142 & 89.31 \\
Age (years) & & \\
18-28 & 36 & 14.45 \\
29-39 & 32 & 19.04 \\
$40-59$ & 85 & 60.11 \\
60 or more & 6 & 6.40 \\
Profession/occupation & & \\
Beneficiary of the National Institute of Social Security & 66 & 41.51 \\
Student & 23 & 14.47 \\
Health professional & 17 & 10.69 \\
Others & 26 & 16.35 \\
No information & 27 & 16.98 \\
Locale & & \\
Rio Grande do Sul, Brazil & 152 & 95.60 \\
Mato Grosso, Brazil & 3 & 1.88 \\
Bahia, Brazil & 4 & 2.52 \\
\hline & &
\end{tabular}

Although May presented 61 (38.36\%) attendances, April had $49(30.82 \%)$ in 18 days of reception. This number was decreasing in subsequent months. In addition, more than $89 \%$ of accesses were women, predominantly the age group of 40 to 59 years $(n=$ $85 ; 60.11 \%)$; and $41.51 \%$ of people $(n=66)$ who accessed the chat received benefits from the National Institute of Social Security (INSS).

About the locality in which the person was at the time of access, 152 (95.60\%) were in the state of Rio Grande do Sul, with a predominance in the city of Pelotas (132; 86.84\%), in addition to the States of Mato Grosso, with 3 (1.88\%) accesses; and Bahia, with 4 (2.52\%).

Regarding the main emotional responses and complaints presented in the chat hosts, anxiety was present in 99 attendances, followed by fear $(n=58)$, depression $(n=57)$, sadness ( $n$ $=56)$, anxiety $(\mathrm{N}=17)$, crying $(\mathrm{N}=13)$, stress $(\mathrm{N}=9)$ and suicidal ideation ( $\mathrm{N}=7$ ). In five contacts, insomnia, nervousness, and panic appeared. In smaller numbers, there were manifestations of panic, discouragement, tightness in the chest, lack of appetite, irritability, tension, and worry.

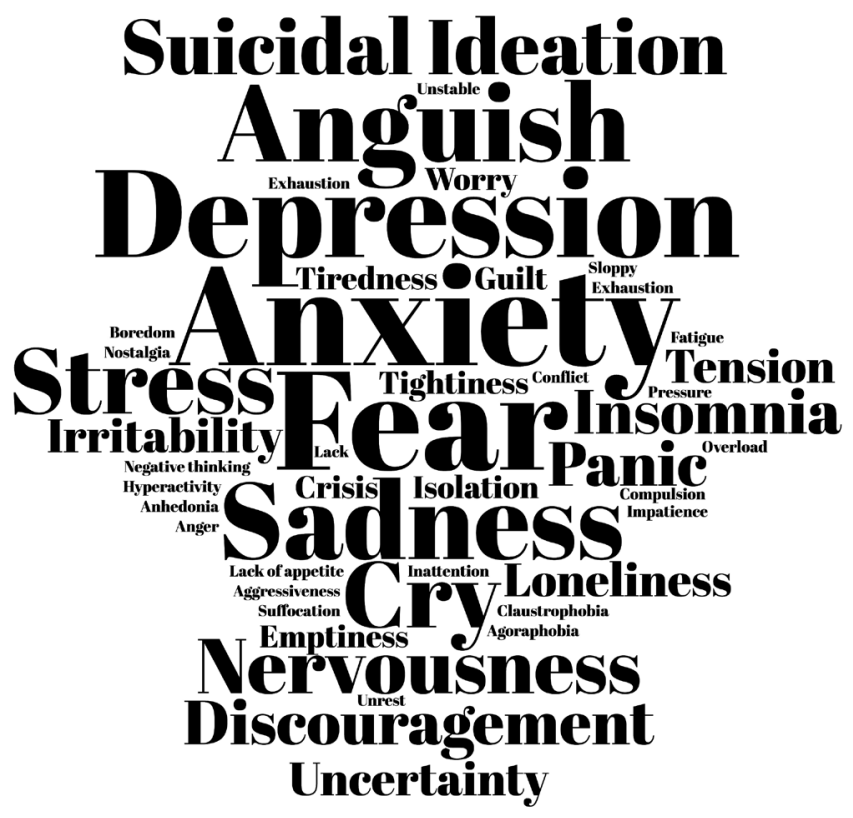

Figure 1 - Word cloud based on the emotional responses presented by the 159 people served from the therapeutic listening chat

\section{DISCUSSION}

China identified the first case of COVID-19 in December 2019. In Brazil, it occurred on February 26, 2020 (in the State of Rio Grande do Sul on March 10, and in the city of Pelotas on March 25). The progress of the disease occurred rapidly, considering that, in the period of data collection of this research, on April 13, there were 23,604 confirmed cases and 1,333 cumulative deaths in the country; 664 cases and 16 deaths in the State of Rio Grande do Sul. On July 13 , the pandemic progressed with 1,884,967 cases and 72,833 deaths in Brazil; and 39,656 cases and 995 deaths in the State of Rio Grande do Sul ${ }^{(12)}$. The COVID-19 pandemic has behaved differently in Brazilian states. The onset of cases in Brazil and the State of Rio Grande do Sul coincided with the period of higher demand for chat service (April and May 2020). This increase in the search for care may be linked to the rapid spread of the virus, fear, and uncertainties in the face of limited knowledge about the behavior of COVID-19 in such particular and different territories of the country.

\section{Features of online service users}

The results showed that the online mental health visits performed were mostly with female users. These findings corroborate a cross-sectional study conducted in Ribeirão Preto, State of São Paulo, which points to a greater number of women seeking healthcare services, 1.9 times greater than men ${ }^{(13)}$.

The demand for and engagement of women in health care are factors that also rebound on mental health. A survey on COVID-19 preventive behaviors and mental health in Turkey, with 3,190 adults, found that women were more likely to identify the severity 
of the disease and, therefore, to take preventive behaviors. The authors noted that recognition of the severity of COVID-19 had a significant positive impact on participants' preventive behaviors and mental health ${ }^{(14)}$.

In the present study, the people served in the chat were mostly between 40 and 59 years old. The lowest demand for online mental health care was for people aged 60 and over. Concerning this data, it is necessary to emphasize that the online service implemented in April 2020, the initial period of the pandemic, even if given in a public service chat, without costs and easy access by internet, does not become accessible to all people. Some of them may have difficulties using smartphones or computers. It happens more often with the elderly, for example, the age group with the highest number of complications and deaths from COVID-19. Older people may not be adept at digital technologies and may need technical support during the first calls. In addition, knowledge of countries with a history of deploying digital services to widely dispersed populations (such as Australia and Canada) can be useful ${ }^{(15)}$.

As for occupation, the result corroborates a study in which confirms that being retired/pensioner is a facilitating factor for the demand for health services ${ }^{(13)}$. In contrast, the present study showed that the lowest demand for online care was due to health professionals. During the pandemic, the daily challenges of health professionals include the high workload, the lack of knowledge about the disease, the lack of adequate personal protective equipment, as well as the fear of becoming infected and taking the virus to their families ${ }^{(16-17)}$. In a study with frontline health professionals in hospitals in China, 560 (44.6\%), among doctors and nurses, had symptoms of anxiety and $50.4 \%$ depression ${ }^{(18)}$. In a study conducted in France with health workers of intensive care units, a prevalence of symptoms of anxiety, depression, and peritraumatic dissociation in the order of $50.4 \%, 30.4 \%$, and $32 \%$, respectively, was found ${ }^{(19)}$. Despite being highly exposed to contamination and under relevant emotional pressure, health professionals have demonstrated resistance in seeking mental health support services ${ }^{(16,20)}$.

Another significant factor about the characteristics of the people who accessed the chat was their location. Most of them came from the state of Rio Grande do Sul. It probably occurred because the University which was linked to the extension project has its campus in this state, and the dissemination carried out on social networks, community radio, television newspaper, among others, happened through students, teachers, and professionals who resided in this state.

\section{Motivations for seeking care}

Factors such as the severity of the disease, high capacity for contagion and spread of COVID-19, absence of effective treatments, health measures of social distancing/quarantine/isolation, insecurity regarding the measures adopted by the rulers, and extensive exploitation of data without scientific basis in the media marked the context of the pandemic.

To that end, overwhelming news and isolation measures can change people's perception and trigger emotions, insecurities, symptoms that evoke the need to seek mental health care $^{(21)}$. A study on media coverage of disasters examined the association between media consumption and psychological outcomes. The conclusion was that exposure to stressful media coverage of major disasters is associated with an increase in psychological anxiety and can trigger cases of post-traumatic stress disorder, depression, anxiety, stress, stress reactions, and substance ${ }^{(22)}$.

Also, the spread of misinformation about COVID-19, which irritates the scientific community and society - from the various theories about the origin of the virus on the internet, confusing and erroneous information on how to reduce transmission and exposure to the virus, to miracle remedies such as vitamin $C$ and garlic, and others - can have a devastating impact on the population. Given this rampant dissemination, as well as worldwide media coverage of the pandemic, individuals can be exposed to it even without deliberately seeking it ${ }^{(23)}$.

The lack of confidence in the political actions of managers and rulers also contributes to people's insecurity. A study conducted in the United States (N. 808) and Canada (N. 1,354) reaffirmed the impact of the pandemic on mental health by indicating that a third of Canadians surveyed were concerned about the virus, and 33\% were not confident that the local health system was prepared to deal with new cases. In the United States, $56 \%$ were very concerned about the spread of the coronavirus, and $26 \%$ of respondents felt that the government was not doing enough to stop the spread ${ }^{(24)}$.

When assessing the impact of the COVID-19 pandemic on the mental health of the population in 194 cities in China, a study showed that $53.8 \%$ of respondents rated the psychological impact of the outbreak as moderate or severe, $16.5 \%$ reported moderate to severe depressive symptoms, $28.8 \%$ reported moderate to severe anxiety symptoms, and $8.1 \%$ reported moderate to severe stress levels ${ }^{(25)}$.

Often, the psychosocial implications are secondary to the phenomenon, both at the individual and collective level since it is natural that, in a pandemic context, health professionals, scientists, and managers focus on the pathogen and biological risk, seeking to know the pathophysiological mechanisms involved to propose measures for the prevention, control and treatment of the disease. The pandemic formed in a different context from other humanitarian emergencies such as the September 11 attack in the United States and the fire at the Kiss Nightclub in Brazil when authorities quickly organized psychological assistance task forces for victims and their families ${ }^{(26)}$.

This tendency to underestimate and neglect the psychosocial implications of a pandemic generate gaps in coping strategies and increasing the burden of associated diseases. Thus, the number of people affected in their mental health tends to be higher than the number of people infected by the new coronavirus, demonstrating that the implications for mental health have a higher prevalence and can last longer than the pandemic ${ }^{(26)}$. Therefore, it is essential in the training and practices of health professionals, including nurses, to understand the psychosocial consequences of the COVID-19 pandemic to organize the health services network to meet these demands.

Although the psychosocial implications of the pandemic reach a large part of the population, not all manifestations turn into psychiatric disorders. A strong emotional response to the atypical context of the pandemic is expected, so the first care in 
mental health is strategically decisive in this life path of people. Thus, we chose to present the data collected in the 159 records of the people served in the chat based on the emotional manifestations that were most evident in the analysis of these records, translated into themes such as fear, depression, anxiety, sadness, crying and suicidal ideation.

\section{Anxiety and fear}

Respectively, 99 and 58 people served in the chat manifested subjective expressions of anxiety and fear as a response to the emotional demands constituted during the COVID-19 pandemic.

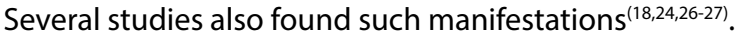

Fear often generates anxiety, which is probably the case of COVID-19 due to its novelty and uncertainties about how bad the current outbreak can become ${ }^{(24)}$. Fear is a defense mechanism that helps to prepare a response to threatening events through various biological processes. However, if it is experienced chronically or disproportionately, such as in the case of a pandemic, it can increase anxiety and stress levels in healthy individuals and intensify the symptoms of pre-existing psychiatric disorders ${ }^{(26)}$.

COVID-19 came to shake the alleged control due to the scientific advances achieved that society believed to possess and showed the insecurities and frailties regarding control over diseases and death. In this way, we can see how restless and frightening this respiratory syndrome is due to its aggressive character and its rapid rate of contagion. The fear produced by the pandemic has several origins: fear of contamination, loss or alteration of income, of losing something or someone due to the virus, or isolation ${ }^{(28)}$.

In a systematic review and meta-analysis, when analyzing the prevalence of anxiety and depression in the general population during the COVID-19 pandemic, we identified the prevalence of anxiety of $31.9 \%$ in a sample of 63,439 people, considering 17 studies and the predominance of depression was $33.7 \%$ in another sample of 44,531 people from 14 studies. All analyzed studies that examined psychological disorders during the COVID-19 pandemic reported several predictive symptoms of mental health problems ${ }^{(29)}$. Nervousness and anxiety affect people in general, but evidence confirms that people, when kept in isolation and quarantine, experience significant levels of anxiety, anger, confusion, stress, depression ${ }^{(30)}$.

\section{Depression, sadness, crying and suicidal ideation}

In the data obtained from the medical records of people served online in the chat, emotional responses to the pandemic such as depression ( $n=57)$, sadness $(n=56)$, crying $(n=13)$, suicidal ideation $(n=7)$ they stand out in the cloud of words as an emotional expression of the moment.

Quarantine, social distancing, and isolation have made life experiences acquire a new configuration because the silence of the external world has made internal noises emerge and, with these, new expressions of sadness, depression, and a sense of loss of meaning of life, given the anguish generated by the security bargain versus the expansion of restrictions that limit the exercise of free choice ${ }^{(28)}$. Some of the manifestations of sadness, demotivation, anguish, and crying are already referred to as depression by the people treated, being expressed in the medical records as self-reports, through an indistinct understanding of the population, making a distinction between the sorrows of life and its unpredictability and depression as a diagnosis.

In pandemics, there are many losses, both of human lives and routines, face-to-face social connections, and financial stability. COVID-19 has produced rapid changes in the daily lives of people, who have had to deal with the unpredictable future ${ }^{(31)}$, and this unpredictability can be one of the factors to trigger sadness and even suicidal ideation.

Studies are incipient concerning the risk of suicide and suicides committed due to the psychosocial consequences that the pandemic produced. There are few cases reported worldwide of people who, due to fear of COVID-19 infection, social stigma, isolation, depression, anxiety, emotional imbalance, job loss, and financial insecurities have taken their own lives. This information is of utmost importance, as it allows us to predict the ripple effect of this virus on suicidal events around the world, as well as to know the main associated factors ${ }^{(32)}$.

\section{Study limitations}

The regionality of the study stands out because, even though the therapeutic listening chat is available throughout Brazil, it was accessed predominantly by users from the southern region of the country. Also, the limitations of some people in using technologies, such as smartphones or computers, and the fact that not all people have access to the internet, are mentioned as a barrier.

\section{Contributions to the fields of Nursing and Health}

The results reinforce the importance of therapeutic listening (which is part of the duties of the nurse) as an essential instrument of reception, care, and intervention; and, especially, mental health support to the entire population as a way of coping with the impact of the COVID-19 pandemic.

\section{FINAL CONSIDERATIONS}

This article demonstrates that online care is an opportunity for a quick, early, and short waiting time intervention for people who present some kind of psychic suffering and need care during the pandemic. Through this contact with professionals, people could express their feelings and find comfort during the difficult times they are experiencing. The feelings mentioned by the participants as anxiety, fear, and sadness demonstrate that people need to be assisted because, due to social isolation, the access to a care unit becomes more difficult. Therefore, chat presents itself as a tool that allows convenient access to the user since he can be anywhere.

The remote therapeutic listening was efficient in the pandemic context since people could express their feelings to a specialized team in an environment in which professionals did not focus on diagnosis and medicalization but the sensitivity of reception to the sensitive demands of each person.

In addition, the Research Group access through the website does not require the installation of an additional application or 
registration on a social network. Text communication uses little internet data, generating savings, and it can be used in low-speed connections.

This study emphasizes the need to increase the health professionals awareness about the usefulness of online mental health interventions, as well as investments in this area during the academic training of health professionals, especially nurses because these are professionals present and working in different health services. In addition to the competencies and skills in the care of the human being in its entirety, nursing has been expanding its space in the area of mental health proactively and decisively concerning the needs of people in psychic suffering.

\section{FUNDING}

The authors thank the Research Support Foundation of the State of Rio Grande do Sul - Fapergs (Fundação de Amparo a Pesquisa do Estado do Rio Grande do Sul), Brazil, for funding this research through the Emergency Bid FAPERGS 06/2020 - Science and Technology in the fight against COVID-19.

\section{REFERENCES}

1. Qiu J, Shen B, Zhao M, Wang Z, Xie B, Xu Y. A nationwide survey of psychological distress among Chinese people in the COVID-19 epidemic: implications and policy recommendations. Gen Psychiatr. 2020;33(2):e100213. https://doi.org/10.1136/gpsych-2020-100213

2. Rajkumar RP. Covid-19 and mental health: a review of the existing literature. Asian J Psychiatr. 2020;52:102066.: https://doi.org/10.1016/j. ajp.2020.102066

3. Tian F, Li H, Tian S, Yang J, Shao J, Tian C. Psychological symptoms of ordinary Chinese citizens based on SCL-90 during the level I emergency response to covid-19. Psychiatry Res. 2020;288:112992. https://doi.org/10.1016/j.psychres.2020.112992

4. Ramírez-Ortiz J, Castro-Quintero D, Lerma-Córdoba C, Yela-Ceballos F, Escobar-Córdoba F. Mental health consequences of the covid-19 pandemic associated with social isolation. Colomb J Anesthesiol. 2020;48(4):e930. https://doi.org/10.5554/22562087.e930

5. Pereira MD, Oliveira LC, Costa CFT, Bezerra CFT, Pereira MD, Santos CKA, et al. The covid-19 pandemic, social isolation, consequences on mental health and coping strategies: an integrative review. Res Soc Dev. 2020;9(7):e652974548. https://doi.org/10.33448/rsd-v9i7.4548

6. Torous J, Keshavan M. COVID-19, mobile health and serious mental illness. Schizophr Res. 2020;218:36-7. https://doi.org/10.1016/j. schres.2020.04.013

7. Schmidt B, Crepaldi MA, Bolze SDA, Neiva-Silva L, Demenech LM. Mental health and psychological interventions during the new coronavirus pandemic (covid-19). Estud Psicol. 2020;37:e200063. https://doi.org/10.1590/1982-0275202037e200063

8. Danzmann PS, Silva ACP, Guazina FMN. Atuação do psicólogo na saúde mental da população diante da pandemia. J Nurs Health. 2020;10(4):e20104015. https://doi.org/10.15210/JONAH.V1014.18945

9. Faria GM. Therapeutic alliance constitution in online psychoterapy: gestalt-therapy perspectives. Rev Nufen. 2019;11(3):66-92. http://doi. org/10.26823/RevistadoNUFEN.vol11.n03artigo59

10. Duan L, Zhu G. Psychological interventions for people affected by the covid-19 epidemic. Lancet Psychiatry. 2020;7(4):300-2. https://doi. org/10.1016/S2215-0366(20)30073-0

11. Conselho Federal de Enfermagem. Resolução $n^{\circ} 634$, de 27 de março de 2020: autoriza e normatiza a teleconsulta de enfermagem como forma de combate à pandemia provocada pelo novo coronavírus (Sars-Cov-2). Brasília, DF: COFEN; 2020[cited 2020 Jul 20]. Available from: https://abmes.org.br/arquivos/legislacoes/resolucao-Cofen-634-2020-03-26.pdf

12. Ministério da Saúde (BR). Coronavírus Brasil [Internet]. Brasília, DF: MS; 2020[cited 2021 Jun 6]. Available from: https://covid.saude.gov.br/

13. Levorato $C D$, Mello LM, Silva AS, Nunes AA. Fatores associados à procura por serviços de saúde numa perspectiva relacional de gênero. Cienc Saude Coletiva. 2014;19(4):1263-74. https://doi.org/10.1590/1413-81232014194.01242013

14. Yıldırım M, Güler A. Covid-19 severity, self-efficacy, knowledge, preventive behaviors, and mental health in Turkey. Death Stud. 2020:[about 9 p.]. https://doi.org/10.1080/07481187.2020.1793434

15. Moreno C, Wykes T, Galderisi S, Nordentoft M, Crossley N, Jones N, et al. How mental health care should change as a consequence of the covid-19 pandemic. Lancet Psychiatry. 2020:7(9):813-24. https://doi.org/10.1016/S2215-0366(20)30307-2

16. Chen $Q$, Liang M, Li Y, Guo J, Fei D, Wang L, et al. Mental health care for medical staff in China during the covid-19 outbreak. Lancet Psychiatry. 2020;7(4):e15-6. https://doi.org/10.1016/S2215-0366(20)30078-X

17. Hu D, Kong Y, Li W, Han Q, Zhang X, Zhu LX, et al. Frontline nurses' burnout, anxiety, depression, and fear statuses and their associated factors during the COVID-19 outbreak in Wuhan, China: a large-scale cross-sectional study. EClinicalMedicine. 2020;24:100424. https://doi. org/10.1016/j.eclinm.2020.100424

18. Lai J, Ma S, Wang Y, Cai Z, Hu J, Wei N, et al. Factors associated with mental health outcomes among health care workers exposed to coronavirus disease 2019. JAMA Netw Open. 2020;3(3):e203976. https://doi.org/10.1001/jamanetworkopen.2020.3976

19. Azoulay E, Cariou A, Bruneel F, Demoule A, Kouarchet A, Reuter D, et al. Symptoms of anxiety, depression and peritraumatic dissociation in critical care clinicians managing covid-19 patients: a cross-sectional study. Am J Respir Crit Care Med. 2020;202(10):1388-98. https://doi. org/10.1164/rccm.202006-25680C 
20. Xiang YT, Yang Y, Li W, Zhang L, Zhang Q, Cheung T, et al. Timely mental health care for the 2019 novel coronavirus outbreak is urgently needed. Lancet Psychiatry. 2020;7(3):228-9. https://doi.org/10.1016/S2215-0366(20)30046-8

21. Li W, Yang Y, Liu Z-H, Zhao Y-J, Zhang Q, Zhang L, et al. Progression of mental health services during the covid-19 outbreak in China. Int J Biol Sci. 2020;16(10):1732-8. https://doi.org/10.7150/ijbs.45120

22. Pfefferbaum B, Newman E, Nelson SD, Nitiéma P, Pfefferbaum RL, Rahman A. Disaster media coverage and psychological outcomes: descriptive findings in the extant research. Curr Psychiatry Rep. 2014;16(9):464. https://doi.org/10.1007/s1 1920-014-0464-x

23. Mian A, Khan S. Coronavirus: the spread of misinformation. BMC Med. 2020;18(1):89. https://doi.org/10.1186/s12916-020-01556-3

24. Asmundson GJG, Taylor S. Coronaphobia: fear and the 2019-nCoV outbreak [Editorial]. J Anxiety Disord. 2020;70:102196. https://doi. org/10.1016/j.janxdis.2020.102196

25. Wang C, Pan R, Wan X, Tan Y, Xu L, Ho CS, et al. Immediate psychological responses and associated factors during the initial stage of the 2019 coronavirus disease (covid-19) epidemic among the general population in China. Int J Environ Res Public Health. 2020;17(5):1729. https://doi.org/10.3390/ijerph17051729

26. Ornell F, Schuch JB, Sordi AO, Kessler FHP. “Pandemic fear” and COVID-19: mental health burden and strategies. Braz J Psychiatry. 2020;42(3):232-5. https://doi.org/10.1590/1516-4446-2020-0008

27. Wu K, Wei X. Analysis of psychological and sleep status and exercise rehabilitation of front-line clinical staff in the fight against covid-19 in China. Med Sci Monit Basic Res. 2020;26:e924085. https://doi.org/10.12659/MSMBR.924085

28. Moretti SA, Guedes-Neta ML, Batista EC. Nossas vidas em meio à pandemia da covid-19: incertezas e medos sociais. Rev Enferm Saude Colet [Internet]. 2020[cited 2020 Jul 20];5(1):32-41. Available from: https://revesc.org/index.php/revesc/article/view/57

29. Salari N, Hosseinian-Far A, Jalali R, Vaisi-Raygani A, Rasoulpoor S, Mohammadi SRM, et al. Prevalence of stress, anxiety, depression among the general population during the covid-19 pandemic: a systematic review and meta-analysis. Global Health. 2020;16(1):57. https://doi. org/10.1186/s12992-020-00589-w

30. Brooks SK, Webster RK, Smith LE, Woodland L, Wessely S, Greenberg N, et al. The psychological impact of quarantine and how to reduce it: rapid review of the evidence. Lancet. 2020;395(10227):912-20. https://doi.org/10.1016/S0140-6736(20)30460-8

31. Crepaldi MA, Schmidt B, Noal DS, Bolze SDA, Gabarra LM. Terminalidade, morte e luto na pandemia de covid-19: demandas psicológicas emergentes e implicações práticas. Estud Psicol (Campinas). 2020;37:e200090. https://doi.org/10.1590/1982-0275202037e200090

32. Thakur V, Jain A. Covid 2019-suicides: a global psychological pandemic. Brain Behav Immun. 2020;88:952-3. https://doi.org/10.1016/j. bbi.2020.04.062 